Article

\title{
Carnosic Acid Induces Apoptosis and Inhibits Akt/mTOR Signaling in Human Gastric Cancer Cell Lines
}

\author{
Waseem El-Huneidi ${ }^{1}{ }^{\circledR}$, Khuloud Bajbouj ${ }^{1}{ }^{\oplus}$, Jibran Sualeh Muhammad ${ }^{1}{ }^{\circledR}$, Arya Vinod ${ }^{2}$, Jasmin Shafarin ${ }^{2}$, \\ Ghalia Khoder ${ }^{3}\left(\mathbb{D}\right.$, Mohamed A. Saleh ${ }^{4,5}{ }^{-0}$, Jalal Taneera ${ }^{1,2}{ }^{-}$and Eman Abu-Gharbieh ${ }^{4, *(1)}$ \\ 1 Department of Basic Medical Sciences, College of Medicine, University of Sharjah, \\ Sharjah 27272, United Arab Emirates; welhuneidi@sharjah.ac.ae (W.E.-H.); kbajbouj@sharjah.ac.ae (K.B.); \\ jmuhammad@sharjah.ac.ae (J.S.M.); jtaneera@sharjah.ac.ae (J.T.) \\ 2 Sharjah Institute for Medical Research, University of Sharjah, Sharjah 27272, United Arab Emirates; \\ arya.vinodnadat@gmail.com (A.V.); jsalam@sharjah.ac.ae (J.S.) \\ 3 Department of Pharmaceutics and Pharmaceutical Technology, College of Pharmacy, University of Sharjah, \\ Sharjah 27272, United Arab Emirates; gkhoder@sharjah.ac.ae \\ 4 Department of Clinical Sciences, College of Medicine, University of Sharjah, \\ Sharjah 27272, United Arab Emirates; mohamed.saleh@sharjah.ac.ae \\ 5 Department of Pharmacology and Toxicology, Faculty of Pharmacy, Mansoura University, \\ Mansoura 33516, Egypt \\ * Correspondence: eabugharbieh@sharjah.ac.ae; Tel.: +971-6505-7289
}

check for updates

Citation: El-Huneidi, W.; Bajbouj, K.; Muhammad, J.S.; Vinod, A.; Shafarin, J.; Khoder, G.; Saleh, M.A.; Taneera, J.; Abu-Gharbieh, E. Carnosic Acid Induces Apoptosis and Inhibits Akt/mTOR Signaling in Human Gastric Cancer Cell Lines.

Pharmaceuticals 2021, 14, 230.

https://doi.org/10.3390/ph14030230

Academic Editor: Dejan Stojković

Received: 8 February 2021

Accepted: 3 March 2021

Published: 8 March 2021

Publisher's Note: MDPI stays neutral with regard to jurisdictional claims in published maps and institutional affiliations.

Copyright: (c) 2021 by the authors. Licensee MDPI, Basel, Switzerland. This article is an open access article distributed under the terms and conditions of the Creative Commons Attribution (CC BY) license (https:// creativecommons.org/licenses/by/ $4.0 /)$.

\begin{abstract}
Gastric cancer is among the most common malignancies worldwide. Due to limited availability of therapeutic options, there is a constant need to find new therapies that could target advanced, recurrent, and metastatic gastric cancer. Carnosic acid is a naturally occurring polyphenolic abietane diterpene derived from Rosmarinus officinalis and reported to have numerous pharmacological effects. In this study, the cytotoxicity assay, Annexin V-FITC/PI, caspases 3, 8, and 9, cell cycle analysis, and Western blotting were used to assess the effect of carnosic acid on the growth and survival of human gastric cancer cell lines (AGS and MKN-45). Our findings showed that carnosic acid inhibited human gastric cancer cell proliferation and survival in a dose-dependent manner. Additionally, carnosic acid is found to inhibit the phosphorylation/activation of Akt and mTOR. Moreover, carnosic acid enhanced the cleavage of PARP and downregulated survivin expression, both being known markers of apoptosis. In conclusion, carnosic acid exhibits antitumor activity against human gastric cancer cells via modulating the Akt-mTOR signaling pathway that plays a crucial role in gastric cancer cell proliferation and survival.
\end{abstract}

Keywords: carnosic acid; gastric cancer; apoptosis; Akt; mTOR; caspase; PARP; survivin

\section{Introduction}

Worldwide, gastric cancer (GC) is considered to be one of the most common malignancies, leading to significant annual human cancer deaths [1]. GC is the third largest cause of cancer-related deaths and is a global public health priority [2]. While certain GC subtypes are diminishing due to improved screening, diagnosis, and healthcare services, other subtypes of GC are increasing in their incidence, such as non-cardiac GC in adults [3]. However, the prognosis for advanced, recurrent, and metastatic GC is still unsatisfactory and have very limited treatment options. Therefore, there is an urgent need to find novel and alternative therapies that could target gastric cancer.

Secondary metabolites derived from natural sources, primarily herbal plants, with potential pharmacological properties and less toxicity could be used to synthesize novel pharmaceutical products [4]. Among these natural compounds are the 'terpenes' that have been reported to possess various anticancer pharmacological properties. Diterpenes are a promising group of terpenes that are abundant in nature and are found in a wide variety of plant extracts and animal fats [4]. Carnosic acid is a naturally occurring polyphenolic 
abietane diterpene, as shown in Figure 1, commonly derived from herbal plants like Rosmarinus officinalis. The molecule's pharmacological properties, including antitumor, antiviral, and anti-inflammatory activities, have been reported [5-9]. Previously it was reported that carnosic acid inhibited cell growth and induced cell cycle arrest in B16F10 melanoma cells in addition to the stimulation of p21 expression [5]. It has also been reported that carnosic acid inhibited the growth of estrogen receptor (ER)-negative human breast cancer cells by inducing G1-cell cycle arrest [10]. Carnosic acid showed strong anticancer activity in human cervical cancer cells by inhibiting cell growth and increased the production of reactive oxygen species (ROS) [11]. Furthermore, it downregulated the expression of cyclin A1 in both leukemia and colon cancer cells [12]. Additionally, carnosic acid was reported to induce apoptosis in various other cancer cell lines, including human prostate cancer, neuroblastoma, and hepatocellular carcinoma $[9,13,14]$. While in human hepatoma cells, it inhibited cell growth via targeting the Akt/mTOR pathway leading to autophagy induction [15].<smiles>CC(C)c1cc2c(c(O)c1O)[C@@]1(O)CCCC[C@H]1CC2</smiles>

Figure 1. The chemical structure of carnosic acid.

The antitumor activity of carnosic acid on gastric cancer has never been previously investigated. Therefore, this study aimed to investigate the potential anti-proliferative and anticancer activity of carnosic acid on human gastric cancer cell lines, namely AGS and MKN-45, and explore the underlying molecular mechanism.

\section{Results}

\subsection{Cytotoxic Activity}

To investigate the effects of carnosic acid on gastric cancer cell proliferation, the AGS and MKN-45 cells were treated with increasing concentrations of carnosic acid $(0,1,10$, 25, 50, 100, and $200 \mu \mathrm{g} / \mathrm{mL}$ ) for 24, 48, and $72 \mathrm{~h}$. Carnosic acid treatment decreases cell viability in both cell lines in a dose-dependent manner (Figure 2). In AGS cells, the IC 50 were $19.90,18.93$, and $16.57 \mu \mathrm{g} / \mathrm{mL}$ after 24,48 , and $72 \mathrm{~h}$ incubation, respectively, as shown in Figure 2A. In MKN-45 cells, carnosic acid has $\mathrm{IC}_{50}$ values of 23.96, 20.39, and $17.76 \mu \mathrm{g} / \mathrm{mL}$ after 24, 48, and $72 \mathrm{~h}$ incubation, respectively, as shown in Figure 2B. The concentrations of carnosic acid at 20 and $25 \mu \mathrm{g} / \mathrm{mL}$ for $24 \mathrm{~h}$ were selected for further analysis in AGS and MKN-45 cell lines, respectively, as they were the best representation of $\mathrm{IC}_{50}$.

\subsection{Apoptotic Activity}

Annexin V-FITC/PI double staining assay was used to assess carnosic acid's proapoptotic activity on AGS and MKN-45 cells that were treated with 20 and $25 \mu \mathrm{g} / \mathrm{mL}$ of carnosic acid for $24 \mathrm{~h}$, respectively.

The Annexin V-positive rate revealed that apoptotic cells increased significantly by treating the cells with carnosic acid $(p>0.001)$, as shown in Figure 3 . The early and late apoptotic rates in AGS treated cells were 5.59 and 8.32, respectively, compared to 1.2 and 3.00 , respectively, in the control. 
A

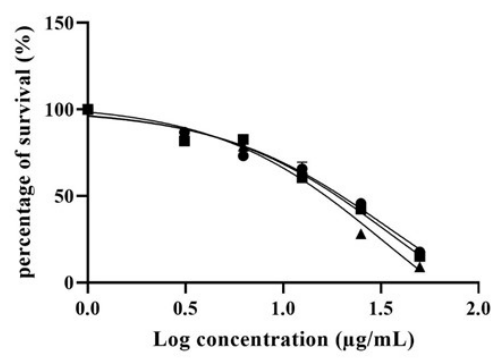

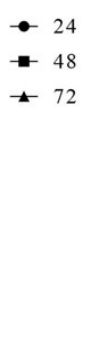

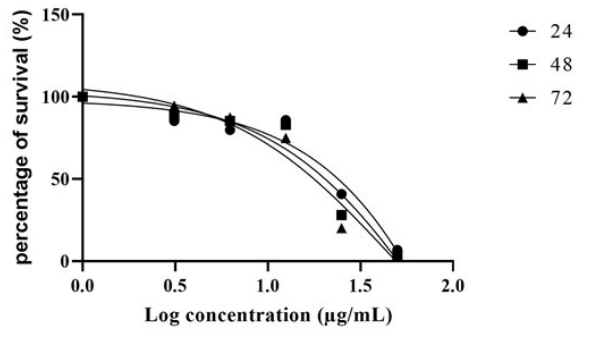

\begin{tabular}{cccc}
\hline Cell Line & $\mathbf{2 4} \mathbf{h}$ & $\mathbf{4 8} \mathbf{h}$ & $\mathbf{7 2} \mathbf{~}$ \\
\hline AGS & $19.90 \pm 1.01$ & $18.93 \pm 2.21$ & $16.57 \pm 1.09$ \\
\hline MKN-45 & $23.96 \pm 2.41$ & $20.39 \pm 1.82$ & $17.76 \pm 1.23$ \\
\hline
\end{tabular}

Figure 2. Effects of the carnosic acid on (A) AGS and (B) MKN-45 cells' viability at three different incubation times (24, 48, and $72 \mathrm{~h}$ ).
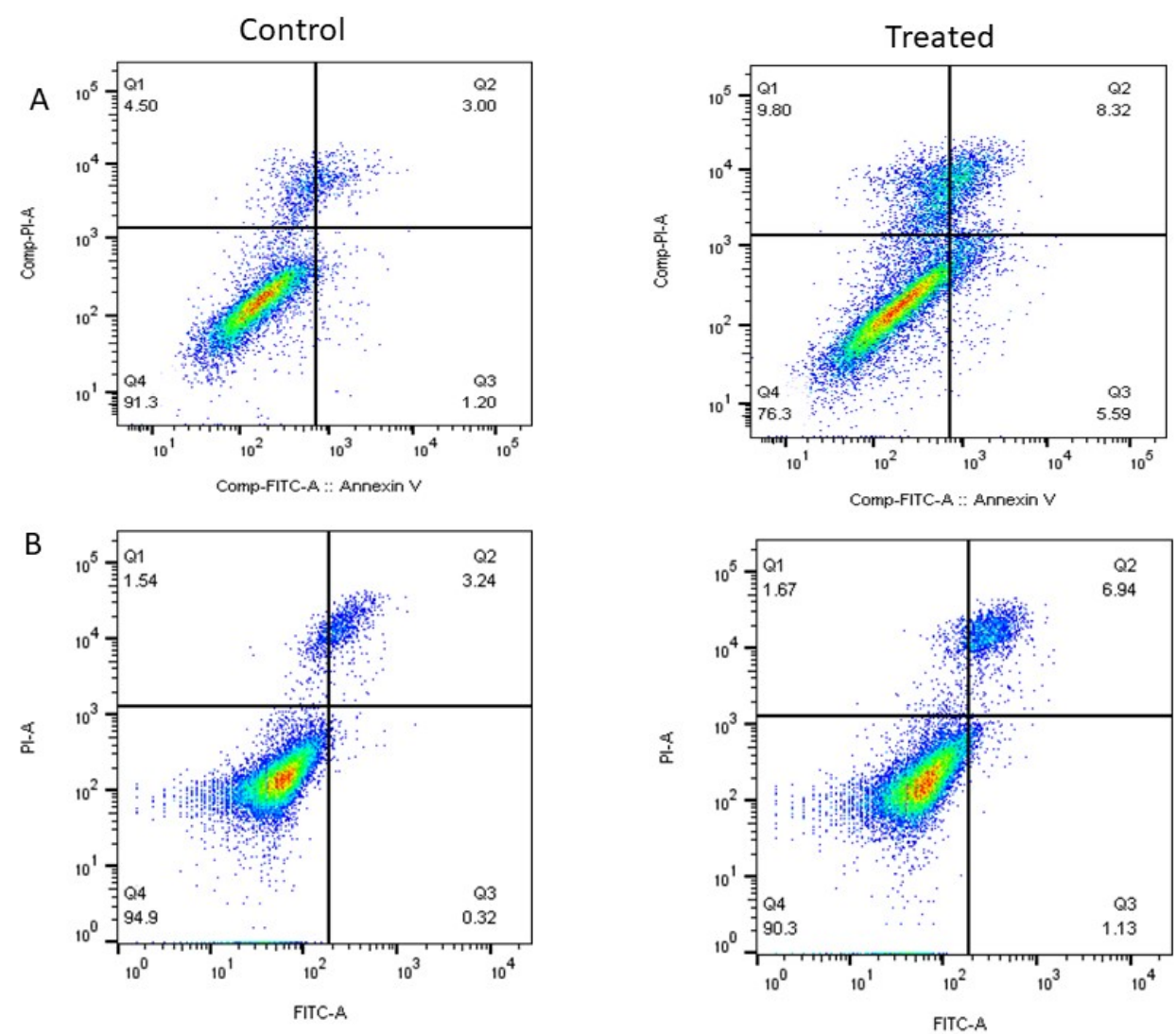

\begin{tabular}{cccccc}
\hline Cell Line & Treatment & Q1 & Q2 & Q3 & Q4 \\
\hline \multirow{2}{*}{ AGS } & Control & $4.50 \pm 0.01$ & $3.00 \pm 0.03$ & $1.2 \pm 0.02$ & $91.3 \pm 0.05$ \\
\cline { 2 - 6 } & Treated & $9.80 \pm 0.01$ & $8.32 \pm 0.02 *$ & $5.59 \pm 0.03 *$ & $76.3 \pm 0.02 *$ \\
\hline \multirow{2}{*}{ MKN-45 } & Control & $1.54 \pm 0.02$ & $3.24 \pm 0.01$ & $0.32 \pm 0.01$ & $94.9 \pm 0.03$ \\
\cline { 2 - 6 } & Treated & $1.57 \pm 0.03$ & $6.94 \pm 0.04^{*}$ & $1.13 \pm 0.06^{*}$ & $90.3 \pm 0.05^{*}$ \\
\hline
\end{tabular}

Figure 3. The level of apoptosis and necrosis was assessed by flow cytometry in (A) AGS and (B) MKN-45 cells, using Annexin V/PI staining. The control groups were without any treatment, and the treated group was treated with 20 and $25 \mu \mathrm{g} / \mathrm{mL}$ carnosic acid in AGS and MKN-45 cell lines, respectively for $24 \mathrm{~h}$. Q1, Q2, Q3, and Q4 represent necrotic cells, late apoptotic, early apoptotic, and living cells, respectively. ${ }^{*} p<0.001$. 


\subsection{Caspase Activity}

To assess carnosic acid's apoptotic effect in AGS cells, the intracellular apoptotic molecular biochemical events were investigated. Figure $4 \mathrm{~A}$ revealed that the activities of caspases 3,8 , and 9 were significantly stimulated in the cells treated with carnosic acid at $20 \mu \mathrm{g} / \mathrm{mL}$ for $24 \mathrm{~h}$ compared to untreated control cells. In addition, PARP cleavage was also noted in the treated cells using $20 \mu \mathrm{g} / \mathrm{mL}$ carnosic acid for $24 \mathrm{~h}$, as shown in Figure 4B.

A

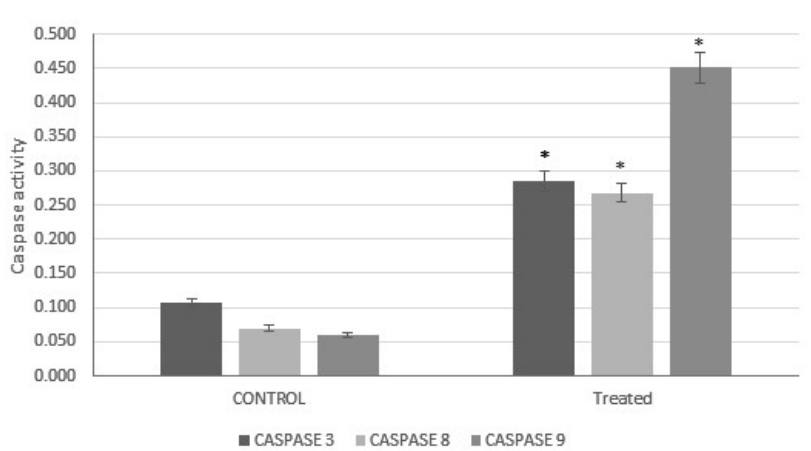

B

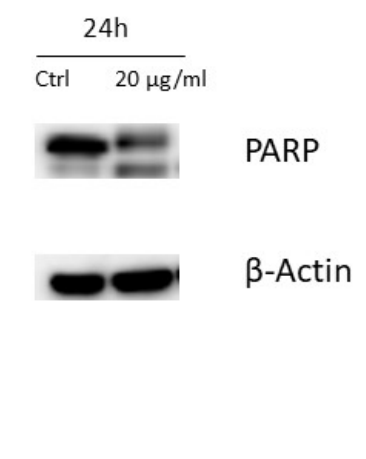

Figure 4. (A) Caspases 3, 8, and 9 activity on AGS cells. The control group received no treatment, and the treated group was treated with $20 \mu \mathrm{g} / \mathrm{mL}$ of carnosic acid for $24 \mathrm{~h},{ }^{*} p<0.001$. (B) The effect of carnosic acid on the cleavage of PARP analyzed by Western blotting. The cells were treated with vehicle (0.1\% DMSO) or treated with carnosic acid at $20 \mu \mathrm{g} / \mathrm{mL} \mathrm{for} 24 \mathrm{~h}$.

\subsection{Cell Cycle Analysis}

To assess carnosic acid's impact on cell cycle progression in AGS cells, the DNA content was measured by flow cytometry. Figure 5 shows that after $24 \mathrm{~h}$ of treatment with $20 \mu \mathrm{g} / \mathrm{mL}$ carnosic acid, there was a marked seven-fold increase in the sub-G1 population in AGS cells, which confirmed apoptosis induction after $24 \mathrm{~h}$. Moreover, treatment with carnosic acid led to a noticeable reduction in both G1 and G2-M phase populations.
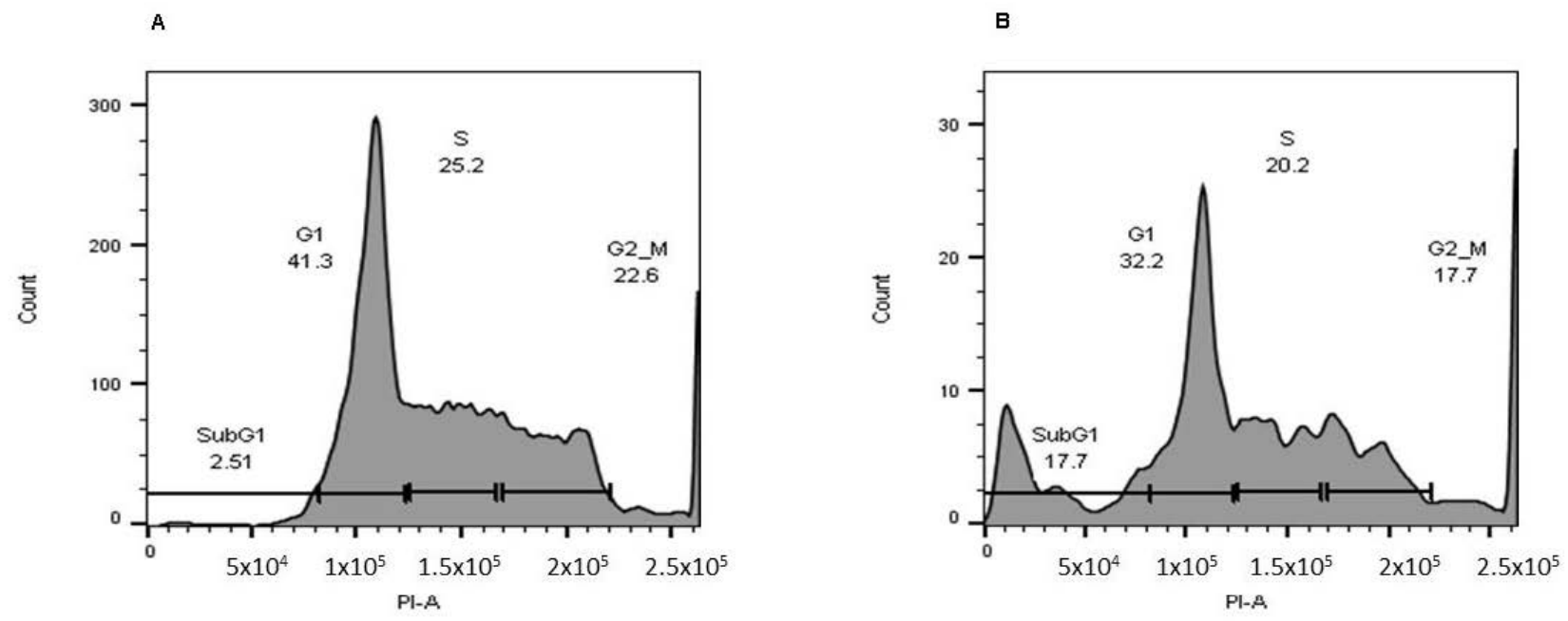

Figure 5. Carnosic acid induces cell cycle arrest in AGS cells. (A) AGS cells treated with DMSO (negative control) and (B) AGS cells treated with the carnosic acid $(20 \mu \mathrm{g} / \mathrm{mL})$ for $24 \mathrm{~h}$. The cell-cycle analysis was performed using flow cytometry, and propidium was used to evaluate the DNA content. 


\subsection{Western Blot}

To investigate the molecular mechanisms involved in apoptotic induction, the expression of several proteins regulating cell death-Phospho-mTOR-S2448, mTOR PhosphoAKT-S473, AKT1, and survivin-were assessed using Western blotting. The cells were treated with vehicle $(0.1 \%$ DMSO) or with carnosic acid at $20 \mu \mathrm{g} / \mathrm{mL}$ for $24 \mathrm{~h}$, representing the $\mathrm{IC}_{50}$ concentration. The findings confirmed a significant reduction in PhosphomTOR-S2448, mTOR, Phospho-AKT-S473, AKT1, and survivin by 53, 33, 30, 27, and 57\%, respectively, when treated with $20 \mu \mathrm{g} / \mathrm{mL}$ carnosic acid for $24 \mathrm{~h}$, as shown in Figure 6.
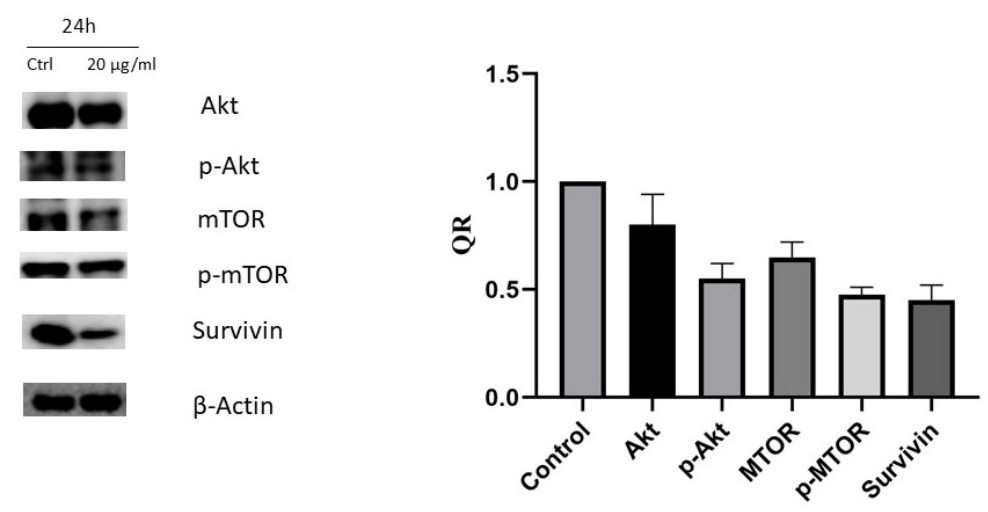

Figure 6. The effect of the carnosic acid on protein expression of AKT1, Phospho-AKT-S473, mTOR, Phospho-mTOR-S2448, and survivin analyzed by Western blotting. The cells were treated with vehicle $(0.1 \%$ DMSO) or treated with carnosic acid at $20 \mu \mathrm{g} / \mathrm{mL}$ for $24 \mathrm{~h}$. The quantitative analysis of each band density after normalization to the control is represented by QR.

\section{Discussion}

The anticancer activity of rosemary has been investigated in several types of cancer [16]. Carnosic acid, a major derivative of rosemary, has been linked with various biological activities, including antioxidant effects, epigenetic modification, anti-inflammatory activity, and regulation of immune systems [17].

To the best of our knowledge, this is the first study to demonstrate the growth inhibitory activity of carnosic acid on gastric cancer cells with $\mathrm{IC}_{50}$ values of 19.90 and $23.96 \mu \mathrm{g} / \mathrm{mL}$ after $24 \mathrm{~h}$ incubation on AGS and MKN-45 cells, respectively. It is worth mentioning that carnosic acid is reported not to affect normal human fibroblast cell viability [18].

To investigate the mechanism by which carnosic acid induces gastric cancer cell death, the Annexin V-FITC/PI assay was performed. Analysis of AGS and MKN-45 cells by flow cytometry showed that carnosic acid induced a shift in the cell population towards apoptosis, and the early and late apoptotic rates increased significantly relative to the control group $(p<0.001)$. It is noted that the cells responded differently to carnosic acid with respect to necrosis. The observed necrotic effect of carnosic acid on AGS cells can be attributed to the possible necroptotic effect, and such effect has been reported previously on other cell lines $[19,20]$.

Apoptosis is regulated via several pathways, of which caspase induction is considered one of the main paths. Caspase activation analysis in this study was performed on caspases 3,8 , and 9 to elaborate both intrinsic and extrinsic pathways. The findings showed that carnosic acid activated all three caspases with the most remarkable activation being that of caspase 9. This suggests that the proapoptotic activity of carnosic acid is mediated through both extrinsic and intrinsic cell death pathways. The cross-communication between the intrinsic and extrinsic pathways is mediated by the cleavage of the proapoptotic Bid (Bcl-2 family member) and explains the marked activation of caspase 9 [21,22]. We also analyzed cleavage of the PARP protein, which is known for being cleaved by activated caspase 3 and, therefore, is essential to the apoptotic pathway [23]. Higher cleaved PARP protein levels $(89 \mathrm{kDa})$ were detected in carnosic acid-treated cells, while only full-length PARP protein $(116 \mathrm{kDa})$ was observed in the untreated cells. 
Cell cycle analysis was performed to explore the molecular mechanisms underlining the observed cytotoxicity and proapoptotic activity of carnosic acid. The results revealed the ability of carnosic acid to induce G1-phase cell cycle arrest on AGS treated cells.

The obtained data are consistent with previously published reports that showed the anti-proliferative activity of carnosic acid on other cancer cell lines [5]. For example, carnosic acid was found to have an antitumor effect and inhibit the growth of estrogen receptor (ER)-negative human breast cancer cells and human cervical cancer cells in addition to prostate cancer, neuroblastoma, and hepatocellular carcinoma $[10,11,13,14,24]$. Moreover, carnosol, a phenolic diterpene isolated from rosemary and structurally related to carnosic acid, has been reported to suppress patient-derived gastric tumor growth by targeting RSK2 [25].

The PI3K/Akt/mTOR pathway is known to be commonly upregulated in various cancers, including gastric cancer [26,27]. Many studies have reported overactivation of the $\mathrm{PI} 3 \mathrm{~K} / \mathrm{AKT} / \mathrm{mTOR}$ pathway and high levels of phosphorylated/activated Akt in gastric cancer $[24,25]$. PI3K is a lipid kinase that phosphorylates membrane phospholipids upon its activation, leading to formation of 3-phosphoinositides, mainly phosphatidylinositol-3,4,5triphosphate (PIP3). PIP3 plays a crucial role in the activation of Akt (the serine/threonineprotein kinase), which is an important promoter of the proliferation and survival of cells [28]. As a consequence of activated Akt, the mammalian target of rapamycin (mTOR) will be activated [29], which will increase protein synthesis and cell proliferation and will inhibit apoptosis [29-31]. Accordingly, the expression of the five proteins (AKT1, Phospho-AKT-S473, mTOR, Phospho-mTOR-S2448, and survivin) were studied based on their contribution to cell growth and proliferation.

Our results showed that carnosic acid significantly downregulated the expression of AKT1, Phospho-AKT-S473, mTOR, and Phospho-mTOR S2448 and survivin proteins, which explains the observed cell cycle arrest along with the proapoptotic activity of the acid on the tested cell line.

mTOR is a signaling molecule that promotes protein synthesis, cell survival, and proliferation, which is usually found activated in cancer [31,32]. Its activation in cancer cells is correlated with a high rate of protein synthesis and autophagy suppression [33,34]. Concurring with these findings, the obtained results confirmed the high levels of phosphorylation/activation of mTOR in untreated AGS cells. While treating the cells with carnosic acid exhibits very potent inhibition of mTOR expression and phosphorylation, this effect could be attributed to the observed inhibition of Akt, an mTOR activator, or through downregulation of other signaling components involved in the mTOR activation pathway [35]. Moreover, reduction in the phosphorylated/activated Akt and mTOR proteins' expression may result in cancer cells being more sensitized to chemotherapies and reducing drug resistance [35]. This finding can be used as a base for future research into carnosic acid's possible use with other chemotherapies used in gastric cancer to improve their efficacy.

Survivin is a protein that acts as a key regulator of cell proliferation and suppression of apoptosis. It is known for not being expressed in normal differentiated tissues but is highly upregulated in most tumors [36]. The overexpression of survivin is usually accompanied by angiogenesis, apoptosis inhibition, and cell proliferation activation [37]. Moreover, in the pre-mitotic phase, survivin binds to spindle microtubules leading tumor cells to escape $\mathrm{G}_{2} / \mathrm{M}$ phase monitoring [38]. This study's findings prove that treatment with carnosic acid downregulates survivin and contributes to the anticancer effect of carnosic acid through activation of apoptosis and inhibition of cell proliferation.

\section{Materials and Methods}

\subsection{Chemicals}

The following chemicals were purchased from Sigma-Aldrich (St. Louis, MO, USA): MTT [3-(4,5-dimethylthiazol-2-yl)-2,5-diphenyltetrazolium bromide tetrazolium], ethanol, and dimethyl sulfoxide (DMSO). The ELISA kits for caspase assays, in addition to the Annexin V-FITC and PI staining assay, were purchased from Abcam (Cambridge, UK). 


\subsection{Cell Lines}

Two human gastric adenocarcinoma cell lines AGS (CVCL 0139) and MKN-45 (DSMZ ACC409) were purchased from CLS (Cell Lines Service, Germany) and DSMZ (Deutsche Sammlung von Mikroorganismen und. Zellkulturen, Germany), respectively. The DMEM/RPMI medium supplemented with $10 \%$ heat-inactivated fetal bovine serum, 10,000 units/mL penicillin, and $10 \mathrm{mg} / \mathrm{mL}$ streptomycin was used to propagate the cells that were maintained at $37^{\circ} \mathrm{C}$ and $5 \% \mathrm{CO}_{2}$ atmosphere.

\subsection{Cytotoxicity Assay}

Carnosic acid was used at different concentrations ranging from 1 to $200 \mu \mathrm{g} / \mathrm{mL}$. Cells were seeded in a 96-well plate $\left(5 \times 10^{3}\right.$ cells/well) and incubated with carnosic acid for 24 , 48 , and $72 \mathrm{~h}$. After treatment, MTT solution was added to the medium, and the cells were incubated at $37^{\circ} \mathrm{C}$ for $2 \mathrm{~h}$. The solubilization of MTT crystals was accomplished by adding $100 \mu \mathrm{L}$ of DMSO followed by a 10 min incubation. Absorbance was measured using a microtiter plate reader at $570 \mathrm{~nm}$. The rate of proliferation was calculated by comparing the absorption of treated cultures with untreated control cultures.

\subsection{Annexin V/PI}

The apoptosis induction was detected using the Annexin-V-PI staining method. In brief, the cells were incubated with $20 \mu \mathrm{g} / \mathrm{mL}$ carnosic acid for $24 \mathrm{~h}$. Then, they were harvested, washed with PBS, and stained for 20 min using the Annexin V-FITC Kit. Finally, the flow cytometer (BD FACS Aria III; Becton Dickinson) was used to analyze the cells for apoptosis at $488 \mathrm{~nm}$ excitation, and a 530/30 nm bandpass filter was used for fluorescein detection. PI-positive cells were considered necrotic; cells positive for annexin V staining were considered early apoptotic, while cells positive for both annexin V and PI were considered late apoptotic. Flowjo software (Tree Star, Ashland, OR, USA) was used to analyze flow cytometry data.

\subsection{Caspase 3, 8, and 9 Assays}

Following the manufacturer's protocol, briefly, AGS cells were incubated with $0.1 \%$ DMSO or carnosic acid at a concentration of $20 \mu \mathrm{g} / \mathrm{mL}$ for $24 \mathrm{~h}$ for control and treated cells, followed by mechanical disruption. Total protein was isolated and quantified by nanodrop. Fifty micrograms of total protein was used to estimate the activity of caspases 3 , 8 , and 9 at $400 \mathrm{~nm}$ absorbance. The percentage of activity was calculated by comparing the absorbance of the treated cells with the untreated ones.

\subsection{Cell Cycle Analysis}

The distribution of different phases of the cell cycle was analyzed using flow cytometry. In brief, the carnosic acid-treated AGS cells $(20 \mu \mathrm{g} / \mathrm{mL}$ for $24 \mathrm{~h})$ were harvested and fixed at $-20{ }^{\circ} \mathrm{C}$ overnight using $1 \mathrm{~mL}$ of $70 \%$ ethanol. After washing with PBS, the cells were stained with PI and DNase-free RNase solution for $30 \mathrm{~min}$. Cells and their progression through various cell cycle phases were then analyzed using a flow cytometry platform.

\subsection{Western Blotting Analysis}

An ice-cold NP40 lysis buffer containing protease cocktail-inhibitor (Sigma-Aldrich) was used to lyse both the carnosic acid-treated and untreated AGS cells. Thirty micrograms of protein was separated using 12\% SDS-PAGE and blotted onto a nitrocellulose membrane (Bio-Rad, Hercules, CA, USA). Skimmed milk was used to block the membrane, followed by washing with tris-buffered saline with $0.1 \%$ tween solution (TBST). The membrane was incubated with primary IgG-unlabeled antibodies of AKT1 (\#A17909), Phospho-AKTS473 (\#AP0637), mTOR (\#A2445), and Phospho-mTOR-S2448 (\#AP0115), purchased from ABclonal technology (Woburn, MA, USA), and survivin (EPR2675) (ab134170) purchased from Abcam, Cambridge, MA, USA, at $4{ }^{\circ} \mathrm{C}$ overnight. Later, the membrane was incubated with secondary antibodies (anti-mouse and anti-rabbit; Cell Signalling Technology) at 
1:1000 dilutions for one hour. Chemiluminescence (Thermo Fisher Scientific, Waltham, MA, USA) and Image Lab software (ChemiDoc Touch Gel and Western blot imaging system; Bio-Rad) were used to detect the bands and quantify band-density, respectively. $\beta$-actin was used as a normalization control.

\subsection{Statistical Analysis}

Prism (GraphPad, V8, San Diego, CA, USA) was used for statistical analyses. The Comparisons between treated and untreated cells were conducted using student's t-test, and a $p$-value of $<0.05$ was considered significant. The dose-response curves were used to calculate the $\mathrm{IC}_{50}$ values. All experiments were performed in triplicate, and data are expressed as the mean \pm standard deviation (SD).

\section{Conclusions}

Carnosic acid inhibits proliferation and induces apoptosis in human gastric cancer cell lines. Mechanistic analysis revealed that carnosic acid induced the expression of caspases 3,8 , and 9, and triggered apoptosis by affecting the Akt/mTOR pathway. This study's findings provide a rationale to initiate in vivo studies to evaluate the efficacy of carnosic acid on animal models as a complement to the currently used chemotherapies against gastric cancer.

Author Contributions: Conceptualization, W.E.-H., E.A.-G.; Methodology, W.E.-H., E.A.-G., K.B.; Statistical analysis, W.E.-H., E.A.-G.; Investigation, W.E.-H., E.A.-G., K.B., A.V., J.S.; Writing-Original Draft Preparation, W.E.-H., E.A.-G.; Data curation, W.E.-H., E.A.-G., G.K., J.S.M., M.A.S., J.T.; WritingReview \& Editing, W.E.-H., E.A.-G., G.K., J.S.M., M.A.S., J.T.; Supervision, W.E.-H., E.A.-G.; Project Administration, W.E.-H., E.A.-G.; Funding Acquisition, W.E.-H. All authors have read and agreed to the published version of the manuscript.

Funding: The study was funded by the College of Research and Graduate Studies, University of Sharjah (No.1801090134-P/VCGSR).

Institutional Review Board Statement: Not applicable.

Informed Consent Statement: Not applicable.

Data Availability Statement: Data are contained within the article.

Conflicts of Interest: Authors declare no conflict of interest.

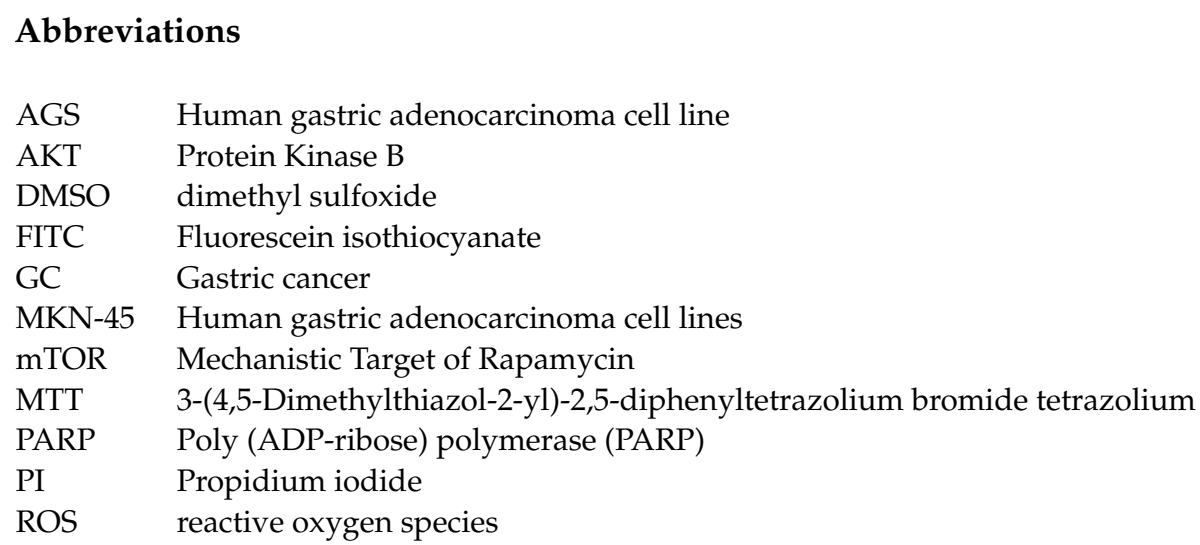

\section{References}

1. Siegel, R.L.; Miller, K.D.; Jemal, A. Cancer statistics, 2017. Cancer J. Clin. 2017, 67, 7-30. [CrossRef]

2. Thrift, A.P.; El-Serag, H.B. Burden of gastric cancer. Clin. Gastroenterol. Hepatol. 2020, 18, 534-542. [CrossRef] [PubMed]

3. Arnold, M.; Ferlay, J.; Henegouwen, M.I.V.B.; Soerjomataram, I. Global burden of oesophageal and gastric cancer by histology and subsite in 2018. Gut 2020, 69, 1564-1571. [CrossRef]

4. Ogbourne, S.M.; Parsons, P.G. The value of nature's natural product library for the discovery of New Chemical Entities: The discovery of ingenol mebutate. Fitoter. 2014, 98, 36-44. [CrossRef] [PubMed] 
5. $\quad$ Park, S.Y.; Song, H.; Sung, M.-K.; Kang, Y.-H.; Lee, K.W.; Park, J.H.Y. Carnosic Acid Inhibits the Epithelial-Mesenchymal Transition in B16F10 Melanoma Cells: A Possible Mechanism for the Inhibition of Cell Migration. Int. J. Mol. Sci. 2014, 15, 12698-12713. [CrossRef] [PubMed]

6. Rajasekaran, D.; Manoharan, S.; Silvan, S.; Vasudevana, K.; Baskaran, N.; Palanimuthu, D. Proapoptotic, Anti-Cell Proliferative, Anti-Inflammatory And Antiangiogenic Potential Of Carnosic Acid During 7,12 Dimethylbenz[A]Anthracene-Induced Hamster Buccal Pouch Carcinogenesis. Afr. J. Tradit. Complement. Altern. Med. 2012, 10, 102-112. [CrossRef] [PubMed]

7. Shin, H.-B.; Choi, M.-S.; Ryu, B.; Lee, N.-R.; Kim, H.-I.; Choi, H.-E.; Chang, J.; Lee, K.-T.; Jang, D.S.; Inn, K.-S. Antiviral activity of carnosic acid against respiratory syncytial virus. Virol. J. 2013, 10, 303. [CrossRef]

8. Tai, J.; Cheung, S.; Wu, M.; Hasman, D. Antiproliferation effect of Rosemary (Rosmarinus officinalis) on human ovarian cancer cells in vitro. Phytomedicine 2012, 19, 436-443. [CrossRef] [PubMed]

9. Tsai, C.-W.; Lin, C.-Y.; Wang, Y.-J. Carnosic Acid Induces the NAD(P)H: Quinone Oxidoreductase 1 Expression in Rat Clone 9 Cells through the p38/Nuclear Factor Erythroid-2 Related Factor 2 Pathway. J. Nutr. 2011, 141, 2119-2125. [CrossRef] [PubMed]

10. Einbond, L.S.; Wu, H.-A.; Kashiwazaki, R.; He, K.; Roller, M.; Su, T.; Wang, X.; Goldsberry, S. Carnosic acid inhibits the growth of ER-negative human breast cancer cells and synergizes with curcumin. Fitoterapia 2012, 83, 1160-1168. [CrossRef] [PubMed]

11. Su, K.; Wang, C.-F.; Zhang, Y.; Cai, Y.-J.; Zhang, Y.-Y.; Zhao, Q. The inhibitory effects of carnosic acid on cervical cancer cells growth by promoting apoptosis via ROS-regulated signaling pathway. Biomed. Pharmacother. 2016, 82, 180-191. [CrossRef]

12. Barni, M.V.; Carlini, M.J.; Cafferata, E.G.; Puricelli, L.; Moreno, S. Carnosic acid inhibits the proliferation and migration capacity of human colorectal cancer cells. Oncol. Rep. 2012, 27, 1041-1048. [CrossRef] [PubMed]

13. Kar, S.; Palit, S.; Ball, W.B.; Das, P.K. Carnosic acid modulates Akt/IKK/NF- $\mathrm{kB}$ signaling by PP2A and induces intrinsic and extrinsic pathway mediated apoptosis in human prostate carcinoma PC-3 cells. Apoptosis 2012, 17, 735-747. [CrossRef] [PubMed]

14. Zhang, X.; Chen, Y.; Cai, G.; Li, X.; Wang, D. Carnosic acid induces apoptosis of hepatocellular carcinoma cells via ROS-mediated mitochondrial pathway. Chem. Interact. 2017, 277, 91-100. [CrossRef]

15. Gao, Q.; Liu, H.; Yao, Y.; Geng, L.; Zhang, X.; Jiang, L.; Shi, B.; Yang, F. Carnosic acid induces autophagic cell death through inhibition of the Akt/mTOR pathway in human hepatoma cells. J. Appl. Toxicol. 2014, 35, 485-492. [CrossRef]

16. Allegra, A.; Tonacci, A.; Pioggia, G.; Musolino, C.; Gangemi, S. Anticancer Activity of Rosmarinus officinalis L.: Mechanisms of Action and Therapeutic Potentials. Nutrients 2020, 12, 1739. [CrossRef] [PubMed]

17. Birtić, S.; Dussort, P.; Pierre, F.-X.; Bily, A.C.; Roller, M. Carnosic acid. Phytochemistry 2015, 115, 9-19. [CrossRef] [PubMed]

18. Min, K.-J.; Jung, K.-J.; Kwon, T.K. Carnosic Acid Induces Apoptosis Through Reactive Oxygen Species-mediated Endoplasmic Reticulum Stress Induction in Human Renal Carcinoma Caki Cells. J. Cancer Prev. 2014, 19, 170-178. [CrossRef] [PubMed]

19. Pérez-Sánchez, A.; Barrajón-Catalán, E.; Ruiz-Torres, V.; Agulló-Chazarra, L.; Herranz-López, M.; Valdés, A.; Cifuentes, A.; Micol, V. Rosemary (Rosmarinus officinalis) extract causes ROS-induced necrotic cell death and inhibits tumor growth in vivo. Sci. Rep. 2019, 9, 1-11. [CrossRef] [PubMed]

20. Park, J.E.; Park, B.; Chae, I.G.; Kim, D.-H.; Kundu, J.; Kundu, J.K.; Chun, K.-S. Carnosic acid induces apoptosis through inactivation of Src/STAT3 signaling pathway in human renal carcinoma Caki cells. Oncol. Rep. 2016, 35, 2723-2732. [CrossRef] [PubMed]

21. Sayers, T.J. Targeting the extrinsic apoptosis signaling pathway for cancer therapy. Cancer Immunol. Immunother. 2011, 60, 1173-1180. [CrossRef]

22. Jelínek, M.; Balušíková, K.; Schmiedlová, M.; Němcová-Fürstová, V.; Šrámek, J.; Stančíková, J.; Zanardi, I.; Ojima, I.; Kovář, J. The role of individual caspases in cell death induction by taxanes in breast cancer cells. Cancer Cell Int. 2015, 15, 1-16. [CrossRef]

23. Boulares, A.H.; Yakovlev, A.G.; Ivanova, V.; Stoica, B.A.; Wang, G.; Iyer, S.; Smulson, M. Role of Poly(ADP-ribose) Polymerase (PARP) Cleavage in Apoptosis. J. Biol. Chem. 1999, 274, 22932-22940. [CrossRef]

24. Tsai, C.-W.; Lin, C.-Y.; Lin, H.-H.; Chen, J.-H. Carnosic Acid, a Rosemary Phenolic Compound, Induces Apoptosis Through Reactive Oxygen Species-Mediated p38 Activation in Human Neuroblastoma IMR-32 Cells. Neurochem. Res. 2011, 36, $2442-2451$. [CrossRef]

25. Wang, L.; Zhang, Y.; Liu, K.; Chen, H.; Yang, R.; Ma, X.; Kim, H.-G.; Bode, A.M.; Kim, D.J.; Dong, Z. Carnosol suppresses patient-derived gastric tumor growth by targeting RSK2. Oncotarget 2018, 9, 34200-34212. [CrossRef]

26. Matsuoka, T.; Yashiro, M. The Role of PI3K/Akt/mTOR Signaling in Gastric Carcinoma. Cancers 2014, 6, 1441-1463. [CrossRef] [PubMed]

27. Ye, B.; Jiang, L.-L.; Xu, H.-T.; Zhou, D.-W.; Li, Z.-S. Exression and PI3K/AKT Pathway in Gastric Cancer and its Blockade Suppresses Tumor Growth and Metastasis. Int. J. Immunopathol. Pharmacol. 2012, 25, 627-636. [CrossRef] [PubMed]

28. El-Huneidi, W.; Shehab, N.G.; Bajbouj, K.; Vinod, A.; El-Serafi, A.; Shafarin, J.; Malhab, L.J.B.; Abdel-Rahman, W.M.; AbuGharbieh, E. Micromeria fruticosa Induces Cell Cycle Arrest and Apoptosis in Breast and Colorectal Cancer Cells. Pharmaceuticals 2020, 13, 115. [CrossRef]

29. Ocaña, A.; Vera-Badillo, F.; Al-Mubarak, M.; Templeton, A.J.; Corrales-Sánchez, V.; Díez-González, L.; Cuenca-Lopez, M.D.; Seruga, B.; Pandiella, A.; Amir, E. Activation of the PI3K/mTOR/AKT Pathway and Survival in Solid Tumors: Systematic Review and Meta-Analysis. PLoS ONE 2014, 9, e95219. [CrossRef]

30. Dienstmann, R.; Rodon, J.; Serra, V.; Tabernero, J. Picking the Point of Inhibition: A Comparative Review of PI3K/AKT/mTOR Pathway Inhibitors. Mol. Cancer Ther. 2014, 13, 1021-1031. [CrossRef] [PubMed] 
31. Mossmann, D.; Park, S.; Hall, M.N. mTOR signalling and cellular metabolism are mutual determinants in cancer. Nat. Rev. Cancer 2018, 18, 744-757. [CrossRef] [PubMed]

32. Aquila, S.; Santoro, M.; Caputo, A.; Panno, M.L.; Pezzi, V.; De Amicis, F. The Tumor Suppressor PTEN as Molecular Switch Node Regulating Cell Metabolism and Autophagy: Implications in Immune System and Tumor Microenvironment. Cells 2020, 9, 1725. [CrossRef] [PubMed]

33. Tian, T.; Li, X.; Zhang, J. mTOR Signaling in Cancer and mTOR Inhibitors in Solid Tumor Targeting Therapy. Int. J. Mol. Sci. 2019, 20, 755. [CrossRef]

34. Hare, S.H.; Harvey, A.J. mTOR function and therapeutic targeting in breast cancer. Am. J. Cancer Res. 2017, 7, 383-404.

35. McKenna, M.; McGarrigle, S.; Pidgeon, G.P. The next generation of PI3K-Akt-mTOR pathway inhibitors in breast cancer cohorts. Biochim. Biophys. Acta (BBA)-Rev. Cancer 2018, 1870, 185-197. [CrossRef] [PubMed]

36. Garg, H.; Suri, P.; Gupta, J.C.; Talwar, G.P.; Dubey, S. Survivin: A unique target for tumor therapy. Cancer Cell Int. 2016, 16, 1-14. [CrossRef] [PubMed]

37. Maia, R.C.; De Moraes, G.N.; Silva, K.L.; Vasconcelos, F.D.C. Survivin overexpression correlates with an apoptosis-resistant phenotype in chronic myeloid leukemia cells. Oncol. Rep. 2011, 25, 1613-1619. [CrossRef]

38. Li, F.; Ambrosini, G.; Chu, E.Y.; Plescia, J.; Tognin, S.; Marchisio, P.C.; Altieri, D.C. Control of apoptosis and mitotic spindle checkpoint by survivin. Nat. Cell Biol. 1998, 396, 580-584. [CrossRef] [PubMed] 